\title{
PRISTANAK OBITELJI ZA UZIMANJEM ORGANA ILI TKIVA OD PREMINULE OSOBE RADI PRESAĐIVANJA U REPUBLICI HRVATSKOJ
}

Sažetak: $\quad$ Republika Hrvatska zemlja je sa sustavom pretpostavljenog pristanka darivanja dijelova ljudskog tijela nakon smrti gdje pristanak obitelji, zakonski, nije jedan od uvjeta za uzimanjem dijelova ljudskog tijela radi presadivanja. No isti je uvjet propisan Kodeksom medicinske etike i deontologije. U ovom radu, autor prvotno predlaže usklađivanje Kodeksa s aktualnim zakonodavstvom. Sukladno tome, u radu se, kritički, prije svega analizira tipologija samog Kodeksa, etička pitanja te etički i pozitivistički razlozi usklađivanja Kodeksa s aktualnim zakonodavstvom. Nadalje, iako autor u prvom redu smatra da Kodeks treba uskladiti sa zakonodavstvom, takoder smatra da je odredba o pristanku obitelji za uzimanjem organa $i$ tkiva sama za sebe manjkava i nekvalitetno razradena. $U$ tom vidu, razmatrajući poredbena zakonodavstva i određene presude Europskog suda za ljudska prava, analiziraju se trenutne odredbe Kodeksa o uzimanju i presađivanju organa i tkiva od preminule osobe te se razmatra koje bi činjenice Kodeks trebao sadržavati kako bi mehanizam pristanka obitelji kod darivanja dijelova ljudskog tijela nakon smrti bio učinkovitiji. Naime, ako autorov prvotni prijedlog za usklađivanjem Kodeksa sa zakonima ne bi bio prihvaćen, autor predlaže makar detaljniju i precizniju razradu već spomenutih trenutnih odredbi Kodeksa, a koje se tiču točnog definiranja obitelji i srodnika te točnih rokova i načina obavještavanja obitelji, ali i preciziranje pojma „etičnosti“ uzimanja organa ili tkiva.

Ključne riječi: $\quad$ pristanak obitelji, Kodeks medicinske etike i deontologije, organi, tkiva, etika

\section{UVODNE NAPOMENE I CILJEVI RADA}

Republika Hrvatska zemlja je sa sustavom pretpostavljenog pristanka darivanja dijelova ljudskog tijela nakon smrti (opt out sustav) koji se temelji na pretpostavci da su svi potencijalni dari-

Tomislav Nedić, mag. iur., doktorand na Pravnom fakultetu Sveučilišta Josipa Jurja Strossmayera u Osijeku. Orahovička 47, 31000 Osijek, Republika Hrvatska. Adresa e-pošte: nedict@gmail.com. 
vatelji nakon smrti, osim ako se za života nisu u pisanu obliku izričito tome usprotivili. ${ }^{1} \mathrm{Naša} \mathrm{je}$ zemlja jedna od vodećih u brojnim aspektima presađivanja organa u Europi, ali i svijetu. Razlog tomu zasigurno jest kvaliteta transplantacijskih timova, ali i kvalitetno i učinkovito uređen pravni sustav presađivanja i darivanja dijelova ljudskog tijela. ${ }^{2}$ Međutim, i u takvom pravnom sustavu postoje određene nedoumice koje mogu voditi do pravne i medicinske nesigurnosti, a tiču se pitanja pristanka obitelji kod uzimanja organa i tkiva radi presađivanja od preminule osobe.

U ovom je radu cilj autora pokazati kako postoji nesklad između našeg zakonodavstva o darivanju dijelova ljudskog tijela nakon smrti i Kodeksa medicinske etike i deontologije ${ }^{3}$ (dalje u tekstu Kodeks) u dijelu oko pristanka obitelji na darivanje. Radi toga će se, zbog same analize određenih pravnih izvora ovog područja u radu, prije svega, dati kratka pozadina svih pravnih izvora koji reguliraju problematiku presađivanja i darivanja dijelova ljudskog tijela u nas. Autor predlaže usklađivanje Kodeksa, kao etičkog akta, s aktualnim zakonodavstvom. Navedena potreba usklađivanja Kodeksa s aktualnim zakonodavstvom proistječe iz točno razrađenih etičkih i pozitivističkih razloga, a posebno načela pacijentova samoodređenja i primata spašavanja ljudskog života te predstavlja nužnost zbog lako mogućih fiktivnih situacija koje se mogu pojaviti i koje mogu staviti liječnike u nezgodan položaj te donijeti dozu nesigurnosti u pravnoj i medicinskoj struci. Autor iz navedenih razloga smatra zakonsko rješenje praktičnijim, ne pokušavajući time pravne norme izdignuti iznad onih moralnih, odnosno etičkih. Unatoč činjenici što autor smatra da Kodeks ne slijedi zakon, i sama je odredba o pristanku obitelji za uzimanjem organa i tkiva manjkava i nekvalitetno razrađena te ako je već stavljena kao uvjet, autor, analizirajući komparativna zakonodavstva te određene presude Europskog suda za ljudska prava, predlaže detaljnu razradu pojedinih instrumenata i mehanizama oko pristanka obitelji kod uzimanja organa i tkiva od preminule osobe u samom Kodeksu, a koji se odnose se na definiranje obitelji i srodnika, točne rokove i načine obavještavanja obitelji te na preciziranje pojma "etičnosti" uzimanja organa ili tkiva.

\section{PRAVNI IZVORI PRESAĐIVANJA I DONACIJE DIJELOVA LJUDSKOG TIJELA U REPUBLICI HRVATSKOJ}

Ustav Republike Hrvatske ${ }^{4}$ predstavlja pravni akt najviše pravne snage te svi ostali pravni akti moraju biti u skladu s istim. U članku 21. jamči se pravo na život, dok se u članku 23. zabranjuje podvrgavanje bilo kakvom obliku zlostavljanja ili, bez vlastita pristanka, liječničkim i znanstvenim pokusima. ${ }^{5}$

$1 \quad$ Bušić, M., Darivanje i presađivanje organa - "Hrvatski model”, Medix, god. XVII., broj 92/93, 2011., str. 144.-148. Vidjeti i Samanta, J., Samanta, A., Medical Law, Palgrave Macmillian, East Kilbride, 2011., str. 311.

2 Službene stranice Ministarstva zdravlja RH, URL= https://zdravlje.gov.hr/vijesti/hrvatska-je-najuspjesnija-clanicaeurotransplanta/369. Pristupljeno 15. ožujka 2017.

3 Kodeks medicinske etike i deontologije, Narodne novine, broj 55/2008, 139/2015.

4 Ustav Republike Hrvatske, Narodne novine, broj 56/1990, 135/1997, 8/1998, 113/2000, 124/2000, 28/2001, 41/2001, 55/2001, 76/2010, 85/2010, 5/2014.

5 Više o liječničkim i zdravstvenim istraživanjima bez informiranog pristanka pacijenta, kao i općenito o povijesnom prikazu informiranog pristanka vidjeti više u: Roksandić Vidlička, S., Galiot, V., Eksperimenti na ljudima kao zločin protiv čovječnosti: Od 
Dva osnova zakona koja reguliraju uzimanje i presađivanje dijelova ljudskog tijela jesu Zakon o presađivanju ljudskih organa u svrhu liječenja ${ }^{6}$ (dalje u tekstu ZPLJO) i Zakon o primjeni ljudskih tkiva i stanica ${ }^{7}$ (dalje u tekstu ZPLJTS), oba iz 2012. godine.

Temeljni zakon u području presađivanja organa jest ZPLJO. Tim se Zakonom utvrđuju "uvjeti za presađivanje ljudskih organa te osiguranje kvalitete i sigurnosti ljudskih organa namijenjenih presađivanju u svrhu liječenja." ${ }^{8}$ Također, Zakon se odnosi na postupke "darivanja, pribavljanja, uzimanja, testiranja, utvrđivanje obilježja darivatelja i organa, te očuvanja, pri-

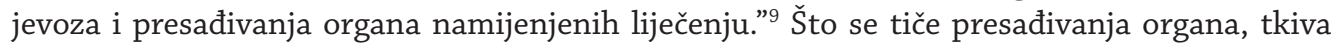
i stanica, prije se primjenjivao Zakon o uzimanju i presađivanju dijelova ljudskog tijela radi liječenja, ${ }^{10}$ odnosno riječ je bila, zapravo, o istom zakonu (ZPLJO), no danom stupanja na snagu ZPLJO-a prestaje važiti Zakon o uzimanju i presađivanju dijelova ljudskog tijela u svrhu liječenja u dijelu koji se odnosi na organe. ${ }^{11}$

ZPLJTS uređuje "uvjete darivanja, prikupljanja, uzimanja, testiranja, obrade, očuvanja, pohrane, raspodjele i primjene ljudskih tkiva i stanica od žive ili s umrle osobe u ljudi." ${ }^{12}$ Također, stupanjem istog Zakona na snagu, prestaje važiti Zakon o uzimanju i presađivanju dijelova ljudskog tijela u svrhu liječenja u dijelu koji se odnosi na tkiva i stanice. Samom tom činjenicom dva nova zakona, ZPLJO i ZPLJTS, anulirali su odredbe Zakona o uzimanju i presađivanju dijelova ljudskog tijela u svrhu liječenja koji je stavljen izvan snage, odnosno predstavlja nevažeći propis. ${ }^{13}$

Ostali propisi, koje je potrebno spomenuti jer su indirektno mjerodavni, jesu: Zakon o liječništvu, ${ }^{14}$ Zakon o zdravstvenoj zaštiti, ${ }^{15}$ Zakon o krvi i krvnim pripravcima, ${ }^{16}$ Zakon o medicinski pomognutoj oplodnji ${ }^{17}$ Zakon o zaštiti prava pacijenta ${ }^{18}$ te Kazneni zakon (dalje $u$ tekstu KZ), ${ }^{19}$ a od podzakonskih akata: Pravilnik o podacima i načinu vođenja dokumentacije

Nürnberškog Medicinskog suđenja do predmeta Pfizer, Godišnjak Akademije Pravnih znanosti Hrvatske, VII (2016), 1, 2016., str. 186. -253

6 Zakon o presađivanju ljudskih organa u svrhu liječenja, Narodne novine, broj 144/2012.

7 Zakon o primjeni ljudskih tkiva i stanica, Narodne novine, broj 144/2012.

8 Zakon o presađivanju ljudskih organa u svrhu liječenja, op. cit. u bilj. 6, čl. 1. st.1.

Ibid. čl. 1. st. 2.

Zakon o uzimanju i presađivanju dijelova ljudskog tijela u svrhu liječenja, Narodne novine, broj 177/2004, 45/2009.

Više u: Nedić, T., Kaznenopravni i medicinskopravni aspekti (ne)dozvoljenog uzimanja i presađivanja dijelova ljudskog tijela u Republici Hrvatskoj, Pravni vjesnik, 32, 1, str. 55.-77.

Zakon o primjeni ljudskih tkiva i stanica, op.cit. u bilj. 7, čl. 1. st. 1.

Zakon o liječništvu, Narodne novine, broj 121/2003, 117/2008.

Zakon o zdravstvenoj zaštiti, Narodne novine, broj 150/2008, 71/2010, 139/2010, 22/2011, 84/2011, 154/2011, 12/2012, 35/2012, 70/2012, 144/2012, 82/2013, 159/2013, 22/2014, 154/2014, 70/2016. 
o mogućim darivateljima dijelova ljudskog tijela radi presađivanja s umrle osobe ${ }^{20}$ i već spomenuti Kodeks medicinske etike i deontologije Hrvatske liječničke komore.

U Republici Hrvatskoj pristanak obitelji nije sadržan u odredbama temeljnih zakona u području presađivanja organa i tkiva - ZPLJO-a i ZPLJTS-a. Međutim, ista je odredba sadržana u Kodeksu koji samim time traži još jedan uvjet više od samih zakona. Ako krenemo od zakona i zakonske regulacije ovog pitanja općenito, možemo doći do brojnih spornih pitanja koji bi u praksi mogli izazvati dvojbe, nesigurnosti te nespretne reakcije. Obvezan pristanak obitelji prisutan je npr. u Srbiji gdje se traži pristanak ne samo darivatelja, nego i njegove obitelji. ${ }^{21}$ Latvija je još jedan primjer potonjeg, gdje je zakonski uvršteno da se obitelj pita o želji preminulog oko darivanja dijelova njegova tijela nakon smrti, što je rezultiralo velikom pravnom nesigurnošću i nedoumicama te dvjema presudama Europskog suda za ljudska prava. ${ }^{22}$

Što se tiče legislative na području Europske unije, potrebno je izdvojiti dvije direktive: Direktiva 2010/53/EZ Europskog parlamenta i Vijeća, od 7. srpnja 2010., o standardima kvalitete i sigurnosti ljudskih organa namijenjenih presađivanju ${ }^{23}$ te Direktivu 2004/23/EZ Europskoga parlamenta i Vijeća, od 31. ožujka 2004., o određivanju standarda kvalitete i sigurnosti za postupke darivanja, nabave, testiranja, obrade, čuvanja, skladištenja i raspodjele tkiva i stanica ljudskog podrijetla. ${ }^{24}$

RH uspješno je implementirala dvije navedene direktive u vlastito, gore spomenuto zakonodavstvo. Naime, ZPLJTS ne primjenjuje se na spolna tkiva i stanice, tkiva i stanice zametka i ploda, krv i krvne pripravke, tkiva upotrijebljena kao autologni presadak unutar istog kirurškog postupka, organe ili dijelove organa ako se u ljudskom tijelu primjenjuju u istu svrhu kao i cijeli organ, te tkiva prikupljena pri uzimanju organa za potrebe zahvata transplantacije istog organa. ${ }^{25} \mathrm{Na}$ područja gdje su ta dva zakona isključena, primjenjuju se Zakon o medicinski pomognutoj oplodnji te Zakon o krvi i krvnim pripravcima. Posljednje navedena direktiva nalagala je državama članicama da u vlastito zakonodavstvo moraju uključiti i reproduktivne stanice, tkiva fetusa i tkiva embrija. RH to nije predvidjela temeljnim zakonom (ZPLJTS), ali je istu odredbu implementirala u ostale već navedene zakone. To je vrlo važno istaknuti s obzirom na to da je Poljsku osudio Sud EU-a jer "je, propuštajući unijeti reproduktivne stanice, tkiva fetusa i tkiva embrija u područje primjene odredaba nacionalnog prava kojima se prenose odnosne direktive, povrijedila svoje obveze iz Direktiva 2004/23, 2006/17, 2006/86 (paragraf 51)."26 Kao članica Vijeća Europe, zajedno s drugim državama te samim EU-om, Hrvatska je potpisnica Konvencije o ljudskim pravima i biomedicini s dva dodatna protokola, ${ }^{27}$ od kojih se

20 Pravilnik o podacima i načinu vođenja dokumentacije o mogućim darivateljima dijelova ljudskog tijela radi presađivanja s umrle osobe, Narodne novine broj 188/2003, 152/2005, 152/2005, 144/2012.

21 Tako srpski Zakon o transplantaciji (Službeni glasnik Republike Srbije, broj 72/2009) traži pristanak člana obitelji ili druge bliske osobe u pisanu obliku (čl. 80.).

22 Više o istim presudama u poglavlju 4. Analiza trenutačnih odredaba o uzimanju i presađivanju organa i tkiva od preminule osobe u Kodeksu.

23 SL L 243, 16. rujna 2010.

24 SL L 102, 7. travnja 2004.

25 Zakon o primjeni ljudskih tkiva i stanica, op. cit. u bilj. 7, čl. 1. st. 4.

26 Predmet C-29/14, Presuda Suda (treće vijeće) od 11. lipnja 2015., Europska komisija protiv Republike Poljske. 
jedan Dodatni protokol odnosi na primjenu u biologiji i medicini i u vezi je s presađivanjem organa i tkiva ljudskog podrijetla.

Godine 2006., samo nepunu godinu nakon postavljanja jasnoga strateškog cilja, Hrvatska je postala pridružena članica Eurotransplanta, a 2007. godine i punopravna članica. ${ }^{28} \mathrm{Na}$ taj je način manjak nacionalne transplantacijske organizacije djelomično uspješno sublimiran članstvom u međunarodnoj organizaciji, koje nam je neosporno donijelo transparentan i čvrsto strukturiran sustav dodjele organa. ${ }^{29}$

Zahvaljujući internetskoj komunikaciji, kao i želji pacijenata u bogatim zemljama da putuju kako bi kupili organ, trgovina ljudskim organima postala je veliki problem na svjetskoj razini. Samim time, u listopadu 2008. godine, Izvršni odbor Eurotransplanta podržao je Istanbulsku deklaraciju o trgovini organima i transplantacijskom turizmu. ${ }^{30}$ Navedenu Deklaraciju donijeli su Međunarodno transplantacijsko udruženje (TTS) i Međunarodno udruženje nefrologa (ISN) te predstavlja potvrdu etičkih načela postavljenih na sastanku u svibnju 2008. u Istanbulu, na kojem je bilo nazočno 150 istaknutih liječnika, dužnosnika, znanstvenika, etičara i pravnika iz 78 zemalja i 20 međunarodnih organizacija. ${ }^{31}$ Iako soft law, Istanbulska deklaracija postaje jedan od glavnih međunarodnih pravnih izvora u području trgovine organima, točno definirajući što sve obuhvaća trgovina organima, što je velik pomak u želji da se stvori međunarodni dokument u kojem će postojati i obvezujuća zajednička definicija što sve obuhvaća trgovanje dijelovima ljudskog tijela. ${ }^{32}$

\section{KODEKS MEDICINSKE ETIKE I DEONTOLOGIJE I AKTUALNO ZAKONODAVSTVO}

\subsection{O KODEKSU MEDICINSKE ETIKE I DEONTOLOGIJE}

Riječ "kodeks" latinska je riječ koja u pravnom krugu označava riječ “zakonik". ${ }^{33}$ Zakonik se definira kao opsežan zakon koji obuhvaća cijelu jednu pravnu granu (npr. građansko pravo) ili pravno područje (npr. pomorsko pravo) i u njemu potpuno i sustavno uređuje sve odnose. ${ }^{34}$ Iako kodeks, Kodeks medicinske etike i deontologije nema zakonsku niti podzakonsku snagu, kao što ga nema nijedan propis (kodeks) profesionalne etike u nas (npr. u odvjetništvu,

28 Bušić, M., op. cit. u bilj. 1 .

29 Ibid.

30 The Declaration of Istanbul on Organ Trafficking and Transplant Tourism, The Transplantation Society (TTS ) and International Society of Nephrology (ISN) in Istanbul from April 30 to May 2, 2008, tekst dostupan na: http://www.declarationofistanbul.org/ about-the-declaration/structure-and-content\#preamble.

31 Službene stranice Hrvatske donorske mreže, URL=http://www.hdm.hr/2008/11/11/istanbulska-deklaracija/. Pristupljeno 13. studenoga 2016.

32 Više o poveznici Istanbulske deklaracije i kaznenog djela nedopuštenog uzimanja i presađivanja dijelova ljudskog tijela u: Roksandić Vidlička, S., Aktualna pitanja pojedinih kaznenih djela protiv zdravlja ljudi u svjetlu donošenja nacrta izmjena hrvatskog Kaznenog zakona, Godišnjak Akademije pravnih znanosti Hrvatske, Vol. 1, No. 1, 2010., str. 93.-146. Riječ codex, -icis, $m$., kao izvedenica od riječi caudex, -icis, $m$. (u prijevodu panj, klada, knjiga, popis) iz Žepić, M., Latinsko-hrvatski rječnik, Školska knjiga, Zagreb, 2000., str. 44. 
sestrinstvu, školstvu itd.) jer ih ne donose državna tijela. ${ }^{35}$ Riječ je o kodificiranim etičkim, a ne pravnim pravilima ponašanja u struci. Etički kodeks treba regulirati ono što izlazi izvan područja prava, polazeći od notorne činjenice da ono što je pravno dopušteno, ne mora biti moralno te bi trebao biti vodilja u redovitom radu tako da bude korektiv između onoga što pravne norme dopuštaju i onoga što dopušta određeni moralni osjećaj. ${ }^{36}$

Godine 1995. dolazi do ponovnog osnivanja Hrvatske liječničke komore čija Komisija za medicinsku etiku i deontologiju donosi Kodeks medicinske etike i deontologije. ${ }^{37}$ Godine 2006. obje su se udruge (Hrvatski liječnički zbor kao neobvezna organizacija te Hrvatska liječnička komora kao obvezna strukovna organizacija) dogovorile o prihvaćanju zajedničkog Kodeksa medicinske etike i deontologije. ${ }^{38}$

Prema Kodeksu, u RH obvezan pristanak obitelji kod uzimanja organa od mrtve osobe, nije propisan zakonom. Zakonodavac poštuje temelje i generalni poredak opt out sustava gdje se prije svega poštuje darivateljeva volja i samoodređenje. No iako ne u zakonu, ista je odredba sadržana u čl. 5. Kodeksa medicinske etike i deontologije Hrvatske liječničke komore gdje se spominje da "nije etično uzimanje dijelova tijela s umrle osobe radi presađivanja protivno volji obitelji ili ako se umrli za života tomu u pisanu obliku protivio." 39

Ovakva odredba, ali i ostale, predstavljaju kodifikaciju utvrđenih etičkih načela ponašanja i postupanja u medicinskoj struci. Na prvi je pogled zanimljivo pitanje tko je uistinu ovlašten da kodificira etiku te podrazumijeva li etički prijestup i određene sankcije jer, također, tko može biti ovlašten za kažnjavanje etičkih, odnosno moralnih prijestupa? Samim time, može se postaviti pitanje je li Kodeks obvezujući u bilo kojem smislu, odnosno može li se liječnik oglušiti o određene norme Kodeksa? Odgovor leži u već spomenutom Zakonu o liječništvu.

Prema čl. 38. Zakona o liječništvu, "Hrvatska liječnika komora donosi Kodeks medicinske etike i deontologije te prati i nadzire njegovo provođenje i sankcionira kršenje.” Prema čl. 45. istog Zakona, "Kodeks medicinske etike i deontologije, polazeći od humanističkih načela i temeljnih vrijednosti društva, utvrđuje načela i pravila kojih se liječnici moraju pridržavati pri obavljanju svog zvanja.” Itekako je bitna odredba iz čl. 50. istog Zakona gdje je liječnik disciplinski odgovoran ako, među ostalim, "povrijedi Kodeks medicinske etike i deontologije Komore". Kodeks ne donosi pravne norme, nego one etičke te samim time ne može zabranjivati, no ako se na temelju kršenja Kodeksa pokreću disciplinski postupci, tada možemo doći do zaključka da Kodeks jest obvezujući u onom profesionalno-etičkom smislu. Odnosno, liječnici bi se mogli naći u situacijama gdje mogu prekršiti ili zakon ili Kodeks te u tom slučaju neće znati kako reagirati. Općenito, kršenje zakona može dovesti do kaznenopravne i građanskopravne odgovornosti, dok kršenje Kodeksa do one disciplinske, što je razrađeno u jednoj od hipotetskih situacija u sljedećem potpoglavlju.

35 Vidjeti više u: Visković, N., Teorija države i prava, Birotehnika, Zagreb, 2001., str. 187.

36 Majstorović, D., Kodeks odvjetničke etike - antinomije prava i morala, Pravo u gospodarstvu, 49, 2010, 3, str. 899.-905.

37 Borovečki, A. (ur.), Mustajbegović, J. (ur.), Priručnik medicinske etike, Croatian Medical Journal: Medicinska naklada, Zagreb, 2010., str. 10 .

38 Ibid.

39 Ista je odredba mijenjana izmjenama i dopunama iz 2015. Prije je glasila: "Dijelovi tijela s umrle osobe smiju se uzeti radi presađivanja samo ako se obitelj tome ne protivi i ako se darivatelj za života nije tome u pisanom obliku protivio.” 


\subsection{ETIČKA PITANJA I ETIČKI RAZLOZI USKLAĐIVANJA}

U ovom je slučaju potrebno odrediti što je etično, a što nije - pristanak obitelji ili činjenica da se sam pristanak ne mora zatražiti. Etika se obično definira kao filozofska disciplina koja ispituje ciljeve i smisao moralnih htijenja, temeljne kriterije za vrednovanje moralnih čina kao i uopće zasnovanost i izvor morala. ${ }^{40}$ Medicinska etika predstavlja analizu odluka koje u cjelokupnoj sferi medicine donosi ne samo liječnik nego i cjelokupno medicinsko osoblje, farmaceuti itd. ${ }^{41}$ Medicinska etika grana je etike koja se bavi moralnim pitanjima medicinske prakse, povezana je s bioetikom (biomedicinska etika), ali nije identična jer bioetika predstavlja vrlo široko područje koje se bavi moralnim pitanjima koja nastaju razvojem bioloških znanosti općenito. ${ }^{42}$

Kada već Kodeks govori o tome što nije ili jest "etično", određene hipotetske situacije najbolje mogu dočarati koliko je ovakav uvjet uistinu etičan. Različitost Kodeksa od zakona stavlja liječnike u nepovoljnu poziciju gdje se mogu naći u situaciji u kojoj ne znaju kako postupiti. Primjerice, određenoj je osobi hitno potreban organ za presađivanje koji može dobiti od osobe koja je nedavno preminula i nije se usprotivila uzimanju za života. Međutim, obitelj preminule osobe usprotivi se uzimanju organa te liječnik samim time ne uzme organ od iste osobe što dovede do toga da osoba kojoj je potreban organ ili premine ili pretrpi teške posljedice za vlastito zdravlje. U takvoj situaciji liječnik koji ne uzme organ ne čini kazneno djelo (budući da KZ ništa ne govori o neuzimanju organa), no obitelj oštećene osobe imala bi zakonski temelj za ulaganjem zahtjeva za naknadom štete jer isti liječnikov čin nije bio u skladu sa Zakonom koji ne propisuje pristanak obitelji kao dodatan uvjet. Nadalje, osim što isti čin nije u skladu sa Zakonom, postavlja se i pitanje koliko je isti čin uistinu etičan. Je li želja obitelji u ovom slučaju važnija od spašavanja ljudskog života? Propisivanje ovakvog uvjeta kao etičnog može iznjedriti ovakve hipotetske situacije kao stvarne gdje se može prekršiti temeljno humanitarno načelo spašavanja ljudskog života što bi trebao biti glavni cilj svakog medicinskog zakonskog ili etičkog akta. Upravo su pomaganje i odgovornost neka od temeljnih načela medicinske etike. ${ }^{43}$ Pomaganje je izraženo pozitivno kao pružanje pomoći, a negativno kao sprječavanje štete te se u medicinskoj tradiciji shvaćalo u vidu načela bonum facere i primum nil nocere, dok se odgovornost kao dužnosno načelo odnosi na moguće posljedice djelovanja ili propusta liječnika. ${ }^{44}$ Samim time, u takvim situacijama, itekako je etično da bi život trebao biti primat u odnosu na želje obitelji, odnosno općenito govoreći svaki potencijalni organ može spasiti novi život te se neuzimanjem organa zbog uskrate obitelji ne daje primat ljudskom životu. S druge strane, ako bi u navedenom slučaju liječnik uzeo organ unatoč protivljenju obitelji, krši vlastiti kodeks koji govori kako to "nije etično" te bi bilo zanimljivo vidjeti bi li disciplinska tijela Komore proglasila istog liječnika disciplinski odgovornim. Svakako se može reći i zaključiti kako ovakva

\footnotetext{
40 Filipović, V., Filozofijski rječnik, Nakladni zavod Matice hrvatske, Zagreb, 1984., str. 97.

41 Veatch, R., M., Medical Ethics, Second edition, Kennedy Institute of Ethics, Georgetown University, Jones and Barlett Publishers, Sudbury, 1997, p. 1.

42 Borovečki, A. (ur.), Mustajbegović, J. (ur.), op. cit. u bilj. 37.

43 Više o načelima medicinske etike vidjeti u: Talanga, J., Odnos liječnika i pacijenta prema medicinskoj etici, Bogoslovska smotra, Vol. 76., No. 1., 2006., str. 47.-59. 
situacija, koja zahtijeva brzu reakciju, nesumnjivo može donijeti veliku dozu nesigurnosti u obavljanju liječničkog poziva kod ovakvih stvari.

Prema Legradiću, hegelovski rečeno - pravo je negacija negacije morala. ${ }^{45}$ Kodeks je punog naziva Kodeks medicinske etike i deontologije. Medicinska deontologija obuhvaća tri međusobno povezane subdiscipline: medicinsko pravo, medicinsku etiku i medicinsku hodegetiku. ${ }^{46}$ Medicinska deontologija proučava i utvrđuje dužnosti medicinskih radnika i ne obuhvaća samo etička načela nego i pravne propise. ${ }^{47}$ Deontološki pristup temelji se na apsolutnim moralnim pristupima i važan je čimbenik u etičkim procjenama mnogih liječnika. ${ }^{48}$ Deontologija, samim time, u sebi obuhvaća i medicinsko pravo. ZPLJO i ZPLJTS, koji su navedeni u radu, dio su medicinskog prava. Isti zakoni ne sadrže u sebi pristanak obitelji kao uvjet. Ako deontologija u sebi obuhvaća medicinsko pravo i etiku skupa, ne bi li tada pravo i etika trebale, barem pokušati, biti u koraku jedno s drugim i oko ovog pitanja? Ne samo zbog navedene konstrukcije da je pravo negacija negacije morala, nego i zato što se u radu naknadno razrađuju sve one hipotetske, ali i stvarne situacije koje su bile dodatno otežane zbog pristanka obitelji kao uvjeta. Tu je i autonomija, odnosno pravo pacijenta na samoodređenje. Zbog već navedenih razloga, pozitivistički, autor smatra zakonsko rješenje praktičnijim, ne pokušavajući time pravne norme izdignuti iznad onih etičkih.

Uz sve navedeno uz samu etičnost, zanimljivo je i pitanje što znači da nešto "nije etično" kako to navodi Kodeks u odredbama o uzimanju i presađivanju organa i tkiva te će isto pitanje biti razrađeno u sljedećem poglavlju u vidu detaljnijih preciziranja odredaba Kodeksa o ovom pitanju.

Glavni je cilj postavki opt out sustava upravo da poveća broj potencijalnih darivatelja te pristanak obitelji kao dodatan uvjet u jednu ruku ruši temelje i samog opt out sustava te ako bismo ovo što propisuje Kodeks bezuvjetno prihvatili, tada bismo kompletni opt out sustav mogli dovesti u pitanje koji kao takav postoji u brojnim državama. Kodeks je pristanak obitelji propisao kao nešto etično, međutim upitno je koliko je takav uvjet u koliziji sa spašavanjem potencijalnog života iz razrađenog hipotetskog primjera uistinu etičan. Također, upitno je koliko je pristanak obitelji kao dodatan uvjet u opt out sustavu uistinu etičan i u skladu s pravilima medicinske etike i deontologije, odnosno krši li se ovdje načelo autonomije, odnosno samoodređenja samog pacijenta kao jedno od temeljnih načela medicinske etike.

\subsection{USKLAĐIVANJE KODEKSA S AKTUALNIM ZAKONODAVSTVOM- NAČELO PACIJENTOVA SAMOODREĐENJA I OPT OUT SUSTAV}

Konkretno i pozitivistički, ako je zakonodavac predvidio da se ne traži pristanak obitelji, postavlja se pitanje zašto to Kodeks traži?

45 Lauc, Z., Moralitet - legitimitet - legalitet, Zbornik radova sa Šestog znanstveno-stručnog interdisciplinarnog skupa Ustavnopravne i obiteljsko-pravne aktualnosti, Osijek, 1. i 2. listopada 2015., Grafika, Osijek, 2016., str. 36.

46 Mašić, I., Medicinska deontologija - principi i praksa u Bosni i Hercegovini, Materia socio media, Vol. 20, No. 1, 2008., str. 7.-13.

47 Salihbegović, E., Medicinska praksa i etičko pitanje, Ministarstvo zdravstva kantona Sarajevo, Sarajevo, 2008., str. 23. 
Također, ukoliko se poštuje odluka obitelji koja nije spojiva s odlukom preminule osobe, utoliko se krši samoodređenje potonjeg te u određenoj mjeri i same osnove opt out sustava. Opt out model ili model pretpostavljenog pristanka jest model gdje je s umrlog dopušteno uzeti organe ako se on tome nije protivio za života. Neizjašnjavanje se smatra pristankom, odnosno pristanak se pretpostavlja. Isti je sustav dugo ukorijenjen u hrvatskom društvu te službeno egzistira još od 1988. godine. ${ }^{49}$ Naime, Hrvatska, Slovenija i Austrija imaju čvrstu tradiciju primjene pretpostavljenog pristanka koji se u navedenim državama temelji na austrougarskom pravu, još iz vremena Marije Terezije, gdje se isti pristanak koristio kod postupka autopsije, no poslije je cijela filozofija prenesena i na donaciju organa. ${ }^{50}$ Upravo je Austrija zemlja s jednom od najvećih stopa doniranih organa u svijetu, a istu činjenicu može zahvaliti upravo vlastitom opt out sustavu koji je dugo godina ukorijenjen u austrijskom društvu. ${ }^{51}$ Belgija je primjer države čija je stopa doniranih organa porasla u onom trenutku kada je počela primjenjivati opt out sustav. ${ }^{52}$ Kako je već rečeno, pristanak obitelji nije tipičan uvjet kod zemalja s opt out sustavom jer je upitno koliko je on u skladu s istim. Naime, u čistim opt out sustavima, srodnici ne bi trebali davati dopuštenje za uzimanje organa, nego je dovoljno da se osoba za života nije izričito tome usprotivila, što je jedno veliko psihološko rasterećenje za samu obitelj u razdoblju stresa i tuge zbog smrti darivatelja. ${ }^{53}$

Ako se RH nalazi u opt out sustavu, tada se pretpostavljeni pristanak mora poštovati u svakoj situaciji, bez određenih proračuna i kalkulacija. Tako ako osoba pogine u prometnoj nesreći nenadano, a za života nije dala izjavu o nedarivanju, tada se ista situacija uistinu mora voditi kao činjenica da on pristaje na darivanje organa. Izgledi da se zna njegovo pravo mišljenje u toj situaciji, polovične su jer je moguće da to ili želi ili ne želi, a budući da se nalazimo u opt out sustavu, trebalo bi ići u prilog prvom, pretpostavci da je on to želio. Isto tako, moguće da je ista osoba uistinu htjela darovati organe kada umre (te samim time nije dala izričitu izjavu o nedarivanju za vrijeme života), no njegova obitelj zabrani darivanje njegovih organa, iako je to osoba uistinu htjela te nije ništa poduzela u vezi s tim pitanjem jer se nalazimo u sustavu pretpostavljenog pristanka koji to podrazumijeva. Tada je ista situacija gora od ove prve jer je povrijeđena stvarna volja pacijenta i njegovo pravo na samoodređenje. Načelo samoodređenja sve se više razvija kao nezavisno načelo u medicinskom pravu u odnosu na načelo paternalizma (tzv. načelo doctor knows the best).$^{54}$ Situacija je lako objašnjiva budući da pozicija pacijenta više nije pasivna jer je obrazovaniji i više ne doživljava liječnika kao autoritet kojemu se treba podvrgavati. ${ }^{55} \mathrm{U}$ nas zakonodavac polazi od toga da je pristanak poseban institut zdravstvenog prava koji proizlazi iz prava pacijenta na samoodređenje i stoga njegov izostanak uzrokuje kažnjivost zahvata koji se obavljaju bez istog pristanka ako je time ostva-

49 Usp. Živčić- Ćosić, S. et al., Development of the Croatian model of organ donation and transplatation, Croatian Medical Journal, Vol. 54, No. 1, 2013., str. 65.-70.

50 Usp. Matesanz, R., Cadaveric organ donation: comparison of legislation in various countries of Europe, Nephrology Dialysis Transplantation, Vol. 13, 1998.,str. 1632.-1635.

52 Ibid.

53 Price, D. P. T., Legal framework governing deceased organ donation in the UK, British Journal of Anaesthesia, 2012, 108 (S1): 68-72. okruglog stola, Rijeka, 2008., str. 163.-171. 
rena sama posljedica. ${ }^{56} \mathrm{Uz}$ to, autonomija pacijenta također predstavlja i jedno od temeljnih načela medicinske etike. ${ }^{57}$ Samoodređenje predstavlja djelovanje zasnovano na pobudama, kriterijima i zakonitostima koje pripadaju samoj ličnosti djelovatelja, nezavisno od izvanjskih utjecaja. ${ }^{58}$ Pojam samoodređenja određeni autori podvode upravo pod pojam slobodne volje, odnosno kao donošenje odluka neovisno o izvanjskim uvjetima, ali se i definira kao sposobnost izbora između različitih mogućnosti, sposobnost donošenja racionalnih odluka itd. ${ }^{59} \mathrm{Su}-$ kladno definicijama samoodređenja i slobodne volje, u slučaju gdje je odluka obitelji suprotna odluci samog pacijenta, nije poštovano pacijentovo pravo na samoodređenje.

Samim time može se reći kako Kodeks u dijelu gdje se traži pristanak obitelji kao uvjet nije u skladu s pravilima medicinske etike i deontologije jer se kombinacijom opt out sustava i pristanka obitelji kao dodatnog uvjeta krši već spomenuto temeljno načelo medicinskog prava i etike - pravo pacijenta na samoodređenje.

U Europi se pravo na samoodređenje i tjelesni integritet izvodi iz prava na privatni život, sadržanog u čl. 8. Europske konvencije za zaštitu ljudskih prava i temeljnih sloboda ${ }^{60} \mathrm{U}$ slučaju Pretty v. United Kingdom ${ }^{61}$ Europski sud za ljudska prava istaknuo je da je koncept privatni život vrlo širok pojam koji je nemoguće odrediti u potpunosti te se granice privatnog života određuju od slučaja do slučaja. Iako dotad nikad nije bilo rečeno da čl. 8. sadržava pravo na samoodređenje, Sud je u istom slučaju naglasio da je pojam osobne autonomije važno načelo koje je temelj za tumačenje jamstava sadržanih u članku. ${ }^{62}$ U slučaju Y. F. v. Turkey ${ }^{63}$ sud naglašava da sukladno čl. 8. "bilo kakvo zadiranje u fizički integritet osobe mora biti propisano zakonom i zahtijeva pristanak osobe. ${ }^{64}$ Europska konvencija za zaštitu ljudskih prava i temeljnih sloboda (čl. 8.), Bioetička Konvencija (čl. 26.) ${ }^{65}$ te sam Ustav (čl. 16.) ${ }^{66}$ eksplicitno određuju da se, među ostalim, prava mogu ograničavati da bi se zaštitile slobode i prava drugih ljudi, što bi značilo da bi se i pravo obitelji moglo ograničiti radi zaštite pojedinca na autonomnu i suverenu odluku o darivanju njegovih organa nakon smrti.

Samim time neusklađenost Kodeksa s aktualnim zakonodavstvom vodi do liječničke nesigurnosti i određene doze samovolje. Isto može samo pridonijeti nesigurnosti u praksi presađivanja dijelova ljudskog tijela. Ako je već zakonodavac izbacio pristanak obitelji kao neobvezan, onda je uistinu upitna potreba za činjenicom da se liječnici vlastitim Kodeksom ograničavaju

56 Usp. Roksandić Vidlička, S., op. cit. u bilj. 32, vidjeti i Turković, K., Roksandić Vidlička, S., Reforma kaznenog zakonodavstva u području zdravstva, Zbornik radova: Aktualnosti kaznenog zakonodavstva u području zdravstva, Novalja, 2011., str. 111.-137.

Talanga, J., op. cit. u bilj. 43.

Filipović, V., op. cit. u bilj. 40, str. 293.

Bezinović, I., Determinizam i slobodna volja, Čemu, Vol. 5, No. 1, 2003., str. 43.-54.

Turković, K., Pravo na odbijanje medicinskog tretmana u Republici Hrvatskoj, Medicina, Vol. 44, No. 2, 2008., 158.-170.

Pretty v. United Kingdom, Application no. 2346/02.

Turković, K., op. cit. u bilj. 60.

Y. F. v. Turkey, Application no. 24209/1994, para 43.

Turković, K., op. cit. u bilj. 60.

"Ne smije biti ograničenja u korištenju prava i zaštitnih odredbi sadržanih u ovoj Konvenciji osim onih koje propisuje zakon i koja su nužna u demokratskom društvu radi interesa javne sigurnosti, sprječavanja zločina, radi zaštite javnog zdravlja ili radi zaštite prava i sloboda drugih."

"Slobode i prava mogu se ograničiti samo zakonom da bi se zaštitila sloboda i prava drugih ljudi te pravni poredak, javni moral i zdravlje. Svako ograničenje slobode ili prava mora biti razmjerno naravi potrebe za ograničenjem u svakom pojedinom slučaju." 
i dovode u nepovoljniji položaj u toj situaciji. To jer ista situacija može smanjiti potencijalne darivatelje. Npr. u austrijskom Zakonu o presađivanju organa (Organtransplantationsgesetz - OTPG ${ }^{67}$ ), koji je konceptualno uvelike sličan hrvatskom te je također izmijenjen 2012., ne postoji odredba o obveznom pristanku obitelji za uzimanje organa. Također, zanimljiva je činjenica da je u već spomenutoj Belgiji početni rast stope doniranih organa stagnirao, a zatim se i smanjio u onom trenutku kada je u bolnicama uveden i obvezan pristanak pacijentove obitelji koji ipak dodatno sužava krug potencijalnih darivatelja. ${ }^{68}$ Određeni medicinskopravni stručnjaci upozoravaju na subjektivne i neracionalne odluke obitelji koje su emocionalno i psihički shrvane gubitkom svojeg člana te samim time uskraćuju pristanak na darivanje organa. ${ }^{69}$

\section{ANALIZA TRENUTNIH ODREDBI O UZIMANJU I PRESAĐIVANJU ORGANA I TKIVA OD PREMINULE OSOBE U KODEKSU}

Također, potrebno je kritički analizirati i trenutačne postavke koje su sadržane u Kodeksu, a tiču se pristanka obitelji za uzimanjem organa i tkiva od preminule osobe. Kako je već rečeno, u RH pristanak obitelji nije zakonski uvjet, no Kodeks ga u etičkom smislu traži.

Kako kaže Wilkinson, riječ je o tzv. dvostrukom vetu gdje svaka strana, preminula osoba i njegova obitelj, ima to ovlaštenje da može uskratiti i prijeći preko želje druge strane da daruje organe nakon smrti. ${ }^{70}$ No Wilknsonova konstrukcija odnosi se na one situacije gdje je pristanak obitelji uvršten kao zakonski uvjet uzimanja i presađivanja. Ako imamo situaciju da Kodeks kao etički propis traži uvjet više od zakona, je li riječ uistinu ovdje o tzv. dvostrukom vetu, odnosno je li, kako je već rečeno, uopće svrsishodno propisivati pristanak obitelji u Kodeksu kao uvjet?

No osim činjenice što nije u skladu sa zakonom, analiza odredbe sadržane u Kodeksu također može dovesti do velikih pitanja i nedoumica. Prije svega, ako je već propisao pristanak obitelji kao uvjet, ne bi li onda Kodeks trebao definirati pojam obitelji i samih srodnika?

Srodstvo jest običajem ili pravom priznata društveno-biološka veza između dviju ili više osoba te s obzirom na činjenicu na kojoj se zasniva, može biti krvno, tazbinsko, građansko, duhovno i dr. ${ }^{71}$ Obitelj je prilično teško definirati, pa tako ona kao zajednica života nije definirana nijednim propisom, ali se iz sadržaja Obiteljskog zakona ${ }^{72}$ vidi da se pojmom obitelji obuhvaća tzv. uža obitelj, odnosno bračni ili izvanbračni drugovi, roditelji i djeca - bračna, izvanbračna, posvojena. ${ }^{73}$ Također, Kazneni zakon u čl. 87. st. 8. eksplicitno navodi da su članovi obitelji

\footnotetext{
67 Organtransplantationsgesetz - OTPG, BGBl. I Nr. 108/12.

68 Cf. Matesanz, R., op. cit. u bilj. 50.

69 Michielsen, P., Presumed consent to organ donation: 10 years' experience in Belgium, Journal of The Royal Society of Medicine, Vol. 98, 1996, pp. 663-666.

Wilkinson, T. M., Individual and family consent to organ and tissue donation: is the current position coherent?, Journal of Medical Ethics, October 2005, Volume 31, Issue 10, pp. 587-590.

71 Vidaković-Mukić, M., op. cit. u bilj. 34, str. 1093.

72 Obiteljski zakon, Narodne novine, broj 103/2015. 
"bračni ili izvanbračni drug, životni partner ili neformalni životni partner, njihova zajednička djeca te djeca svakog od njih, srodnik po krvi u ravnoj lozi, srodnik u pobočnoj lozi zaključno do trećeg stupnja, srodnici po tazbini do zaključno drugog stupnja, posvojitelj i posvojenik."

Vrlo se lako može dogoditi da različiti članovi obitelji imaju različita mišljenja oko darivanja organa umrle osobe. Primjerice, kada dođe do smrti neke osobe, hoće li pravo o odlučivanju oko ovog pitanja imati njegova supruga ili njegovo dvoje djece, pastorčad njegove supruge? Kako postupiti ako supruga daje pristanak, a njegova djeca ne? Ima li tada taj jedan glas za pristanak veću snagu od onih koji ga ne daju? U trenutku koji vrlo često zahtijeva hitnu intervenciju, liječnik se može naći u nezgodnoj situaciji gdje će biti prepušten vlastitoj samovolji: čije mišljenje (od članova obitelji) uzeti u obzir. Diskrecijska je odluka liječnika u tim situacijama prilično velika. Kodeks mora točno definirati obitelj, prema uzoru na ostale zakone gdje se na početku nude definicije ključnih pojmova ili jednostavno da se u okviru istog članka Kodeksa definiraju članovi obitelji te sustav suodlučivanja i prednosti glasova. Upravo kako je to npr. u Zakonu o obveznim odnosima ${ }^{74}$ u čl. 1101. st. 1. gdje stoji kako "u slučaju smrti ili osobito teškog invaliditeta neke osobe pravo na pravičnu novčanu naknadu neimovinske štete imaju članovi njezine uže obitelji (bračni drug, djeca i roditelji). Takva se naknada može dosuditi i braći i sestrama, djedovima i bakama, unučadi te izvanbračnom drugu, ako je između njih i umrlog, odnosno ozlijeđenog postojala trajnija zajednica života (st. 2.).

Također, itekako je upitno značenje termina da nešto "nije etično" kako to stoji u Kodeksu te se postavlja pitanje što je nedostajalo prethodnoj odredbi da je isti termin "etično" dodan u posljednjoj izmjeni Kodeksa? Prema tom će određenju liječnik, kao pravni laik i vrlo vjerojatno ne toliko dobar poznavatelj pravnih normi, teško moći znati kako postupiti jer nije jasno je li uzimanje i presađivanje dijelova ljudskog tijela od preminule osobe bez pristanka obitelji uistinu zabranjeno. Zabrana se ne može propisati prije svega jer je riječ o etičkom aktu, ali i jer bi ona automatski bila protivna zakonima, bez obzira na to da ono što je etično ne mora biti i dijelom zakonske norme i obrnuto. Kako je već utvrđeno, Kodeks donosi ne samo etička pravila, nego i ona deontološka. Kako eksplicitno zabrana ne stoji u Kodeksu, tako se može očekivati od liječnika, kao pravnika laika, razmišljanje da ako nešto nije etično da takvo nešto ne bi trebalo izvršiti. Iako, pitanje je što je tvorac Kodeksa istinski mislio postići koristeći pojam etičnosti. Ako je namjera bila da se postigne zabrana uzimanja ako navedeni uvjeti nisu ispunjeni, tako se isto može postići jedino stavljajući eksplicitnu zabranu u samo zakonodavstvo jer sam Kodeks kao takav ne može zabranjivati određene radnje. Ovakvom se nespretnom regulacijom liječnici stavljaju u prilično tešku situaciju gdje se neće moći znati kako postupiti na onaj način koji je prije svega pravovaljan.

Nadalje, upitno je koliko Kodeks sadržava mehanizam koji bi poučio obitelj o pravu na očitovanje o uzimanju organa s mrtve osobe jer nigdje se ne propisuje način na koji će liječnik kontaktirati s obitelji, sami rokovi itd. Ako "nije etično uzimanje dijelova tijela s umrle osobe radi presađivanja protivno volji obitelji ili ako se umrli za života tomu u pisanu obliku protivio" tada nije etična ni situacija da se detaljno ne razrade i predvide mehanizmi kako da se isto ostvari. U RH liječnik ne može kazneno odgovarati ako propusti pitati obitelj za pristanak, međutim ako se krši Kodeks, onda bi eventualno moglo biti riječi o disciplinskoj odgovornosti liječnika te je zbog toga, ali i da se ostane dosljednim normi o pristanku obitelji u Kodeksu, 
važno da se takva odredba do kraja razradi jer ne postoji drugi pravni akt, osim Kodeksa koji bi tako nešto mogao do kraja definirati s obzirom na to da sam Zakon to ne čini.

Bilo bi eventualno poželjno uvesti poseban informirani pristanak obitelji o ovom pitanju, kao što je to slučaj kod darivanja organa od žive osobe. Međutim, isti je pristanak isključivo predviđen za samog pacijenta nad kojim se treba vršiti zahvat, te bi informirani pristanak obitelji ipak bio presedan svoje vrste u medicinskom pravu. Međutim, ako je u Kodeksu već propisan pristanak obitelji kao uvjet, tako informirani pristanak obitelji u ovom slučaju predstavlja nužnost kako se ne bi dogodile sve one situacije koje ostavljaju liječniku veliku proizvoljnost i diskrecijsku ocjenu te kako bi mehanizam darivanja dijelova ljudskog tijela postao učinkovitiji. Što se tiče informiranog pristanka kod pacijenta, pacijentov pristanak mora biti informiran kako bi bio zakonit, a informiranost podrazumijeva spoznaju, dobrovoljnost, razmatranje, namjeru i razumijevanje. ${ }^{75}$ Koncept informiranog pristanka temelji se na dvije premise: da bolesnik ima pravo na količinu informacija potrebnu kako bi mogao donijeti informiranu odluku o preporučenom medicinskom tretmanu, i drugo, da bolesnik ima pravo prihvatiti ili odbiti prijedlog odnosno preporuku liječnika. ${ }^{76}$ Isti bi se koncepti mogli prenijeti i na obitelj, odnosno da obitelj ima pravo na količinu informacija potrebnu kako bi mogla donijeti informiranu odluku o preporučenom medicinskom tretmanu te pravo prihvatiti ili odbiti prijedlog, odnosno preporuku liječnika. U Zakonu stoji kako "darivatelj mora biti upoznat s njegovim pravima, a osobito o pravu na nepristran savjet u pogledu rizika za zdravlje i to od liječnika koji neće sudjelovati u uzimanju ili presađivanju organa, odnosno koji nije osobni liječnik primatelja." 77 Isto tako, još jedno moguće rješenje jest da se uvede obavijest obitelji, umjesto samog pristanka. Odnosno, da se obitelj ne pita nužno za pristanak oko darivanja organa, nego da ih se obavijesti o činjenici da će organi biti uzeti ili da neće biti uzeti, sukladno odluci pacijenta. U svakom slučaju, europska praksa i nahođenje sugeriraju dijalog liječnika i obitelji, a da bi se to postiglo, mora se točno i sustavno definirati postupak pristanka obitelji kod darivanja i uzimanja dijelova ljudskog tijela.

Latvija je, zbog neuređenog pravnog sustava, neefikasnih mehanizama i neovlaštenog uzimanja dijelova tijela preminule osobe bez mišljenja obitelji čak dva puta izgubila spor pred Europskim sudom za ljudska prava u predmetima - Petrova v. Latvia ${ }^{78}$ i Elberte v. Latvia. ${ }^{79} \mathrm{U}$ predmetu Elberte v. Latvia ${ }^{80}$ Europski sud za ljudska prava utvrdio je kršenja čl. 3. (zabrana mučenja) i 8. (pravo na poštovanje privatnog i obiteljskog života) Europske konvencije za zaštitu

75 Usp. Turković, K., Roksandić Vidlička, S. (ur.), Informirani pristanak, Sveučilište u Zagrebu, Zagreb, $2009 .$, str. 8.

76 Turković, K., op. cit. u bilj. 59.

77 Zakon o primjeni ljudskih tkiva i stanica, op. cit. u bilj. 7, čl. 15. st. 3.

78 Petrova v. Latvia, No. 4605/05, ECHR Judgment 24/9/2014 (Section IV).

79 Elberte v. Latvia, No. 61243/08, ECHR Judgment 13/4/2015 (Section IV).

80 U navedenom predmetu, djelatnici forenzičkog centra uzeli su tkiva iz tijela preminule osobe te ih poslali farmaceutskoj tvrtki iz Njemačke radi stvaranja bioimplatanata. Podnositeljica zahtjeva (inače supruga preminule osobe) nije bila informirana o činjenici uzimanja tkiva s tijela njezina supruga niti je bila poučena o svom pravu da izrazi vlastiti pristanak u vezi s tim pitanjem. Podnositeljica je doznala da je tkivo uzeto s tijela njezina supruga dvije godine poslije, nakon što je u Latviji pokrenuta istraga o brojnim navodima o nezakonitom uzimanju tkiva i organa od preminulih osoba u velikim razmjerima. 
ljudskih prava i temeljnih sloboda, ${ }^{81}$ dok je u predmetu Petrova v. Latvia ${ }^{82}$ utvrđeno kršenje čl. 8. iste.

U predmetu Elberte v. Latvia Europski sud za ljudska prava utvrdio je da države članice moraju odrediti opseg prava srodnika da izraze vlastite prioritete oko uzimanja organa ili tkiva preminule osobe - pod uvjetom da je dotično pravo stvoreno u tuzemnom pravu - te da države članice moraju odrediti odgovarajuću obvezu ili granicu diskrecije prenesenu na stručnjake ili ostale ustanove da objasne ista prava srodnicima. ${ }^{83}$ Ali odgovorom na jedno pitanje, rezoniranje Europskog suda za ljudska prava kritički nameće još jedno - može li postojati samostojeće pravo srodnika da se suprotstave uzimanju organa i tkiva preminule osobe unatoč vlastitim željama preminule osobe, a sve to na osnovi zajamčenog ljudskog prava srodnika na poštovanje privatnog života. ${ }^{84}$ Upravo je to ono što je već spominjano u radu, a to je da se istim činom uvelike krši pravo na samoodređenje preminule osobe.

Zajedničko, u oba predmeta, Europski sud za ljudska prava utvrdio je "određene strukturalne nedostatke koji su prevladavali u području presađivanja organa i tkiva u Latviji" te se obje odluke usredotočuju izravno na kvalitetu tuzemnog prava te je li formulirano dovoljno precizno kako bi bilo dovoljno jasno i predvidivo u njegovoj primjeni. ${ }^{85}$

Latvija, kao zemlja pretpostavljenog pristanka o darivanju dijelova ljudskog tijela nakon smrti, u dva je već navedena predmeta o darivanju dijelova ljudskog tijela nakon smrti izgubila spor pred Europskim sudom za ljudska prava te je u tom trenutku u vlastitu zakonodavstvu, za razliku od hrvatskog, imala odredbe o pristanku obitelji o darivanju dijelova ljudskog tijela. Točnije, latvijsko zakonodavstvo predviđalo je da se organi smiju uzeti samo ako u nacionalnom registru ne postoji zabilježeni pristanak ili odbijanje darivanja organa od strane preminulog i ako je njegova obitelj propustila informirati medicinsku ustanovu o pokojnikovoj želji izrečenoj za njegova života. ${ }^{86}$ Potonje može biti dosta nespretno jer obitelj ne mora nužno znati želje preminule osobe o darivanju organa te će samim time vrlo često obitelj biti ta koja će izreći svoje a ne pokojnikovo mišljenje. ${ }^{87}$ Određena istraživanja u Europi i SAD-u pokazala su da samo oko $50 \%$ onih koji žele darovati organe da su o tome razgovarali s vlastitim obite-

81 Konvencija o zaštiti ljudskih prava i temeljnih sloboda, MU 18/1997, 6/1999, 14/2002, 13/2003, 9/2005, 1/2006, $2 / 2010$. Članak 3.: "Nitko se ne smije podvrgnuti mučenju ni nečovječnom ili ponižavajućem postupanju ili kazni."

(...)

Članak 8.: "Javna vlast se neće miješati u ostvarivanje tog prava, osim u skladu sa zakonom i ako je u demokratskom društvu nužno radi interesa državne sigurnosti, javnog reda i mira, ili gospodarske dobrobiti zemlje, te radi sprečavanja nereda ili zločina, radi zaštite zdravlja ili morala ili radi zaštite prava i sloboda drugih."

U navedenom predmetu liječnici su uzeli organe radi presađivanja od preminule osobe a da o tome nisu obavijestili gđu Petrovu, majku preminule osobe jer je bila riječ o hitnom zahvatu te žurnoj potrebi za organima preminulog. Europski sud zauzeo je stajalište kako "latvijsko pravo koje se primjenjivalo u vrijeme smrti podnositeljičina sina nije precizno formulirano niti da nudi adekvatnu pravnu zaštitu od samovolje" (paragraf 86. presude) budući da gđa Petrova, kako je sama tvrdila, nije bila informirana o mogućem uzimanju organa njezina sina u svrhu presađivanja te nije iskoristila ona prava koja joj navodno omogućuje domaći pravni sustav (paragraf 87. presude).

83 Dove, S., E. et. al, Elberte v. Latvia: Whose tissue is it anyway - Relational autonomy or the autonomy ofrelations?, Medical Law International, pp. 1-20, December 2015.

84 Ibid.

85 Ibid.

86 Petrova v. Latvia, No. 4605/05, ECHR Judgment 24. 9. 2014 (Section IV), paragraf 25, 41.

87 Više o problematici pokojnikovih želja oko darivanja u: Price, D., Human Tissue in Transplantation and Research: A Model Legal and Ethical Donation Framework, Cambridge University Press, Cambridge, 2009., str. 87. 
ljima. ${ }^{88}$ Samim time, lako je moguće da se mišljenje obitelji kosi s istinskim mišljenjem pokojnika o darivanju vlastitih organa, čime se krši njegovo samoodređenje.

Također je bitno napomenuti kako je nečovječno postupanje ili ponižavajuće postupanje iz čl. 3. Europske konvencije za zaštitu ljudskih prava i temeljnih sloboda u nas regulirano zakonom gdje je pri uzimanju organa s umrle osobe potrebno postupati s dužnim poštovanjem prema osobnom dostojanstvu umrle osobe i njezine obitelji. ${ }^{89}$ Navedena je odredba odraz poštovanja prema dostojanstvu preminulog i njegove obitelji te istu odredbu ima npr. i belgijsko zakonodavstvo te austrijsko koje naglašava da uklanjanje organa iz tijela mrtvog darivatelja ne smije rezultirati sakaćenjem tijela koje je nespojivo s dostojanstvom iste osobe. ${ }^{90}$ Razlog tomu jest da je dostojanstvo osobe neodvojivo od dostojanstva ljudskog trupla koje predstavlja osobu koja je nekoć živjela. ${ }^{91}$

Zanimljiva je također činjenica kako Pravilnik o postupku obavještavanja o smrti osoba koje dolaze u obzir kao darivatelji dijelova ljudskog tijela zbog presađivanja u svrhu liječenja, ${ }^{92}$ ne spominje ništa o pristanku obitelji. U čl. 6. stoji kako "nakon utvrđene smrti mozga, bolnički transplantacijski koordinator mora o mogućem darivatelju bez odgode obavijestiti nacionalnog transplantacijskog koordinatora u svrhu provjere statusa umrle osobe u Registru nedarivatelja. Ako se umrla osoba ne nalazi na listi nedarivatelja, bolnički transplantacijski koordinator obavještava obitelj umrlog o namjeri presađivanja dijelova tijela u svrhu liječenja." Tumačeći istu odredbu Pravilnika možemo zaključiti da ni prema spomenutoj odredbi liječnik nema obvezu pitati obitelj za pristanak te da se osobi koja se ne nalazi u Registru smiju beskompromisno uzeti organi radi presađivanja.

\section{ZAKLJUČNE NAPOMENE}

Cjelokupna problematika koja izvire iz područja uzimanja i presađivanja dijelova ljudskog tijela, pa time i iz određenih postavki medicinske i pravne etike, nije nimalo lagana kad je posrijedi usklađivanje i ustanovljavanje. Interesi i želje preminule osobe, interesi i želje njegove obitelji te interesi i želje cjelokupnog društva za uspostavljanjem kvalitetnog zdravstvenog sustava međusobno se isprepleću te je njihovo usklađivanje prilično zahtjevan izazov i zadatak za medicinske, pravne i filozofsko-sociološke stručnjake. ${ }^{93}$ Prema podacima iz 2015. godine

88 Guadagnoli, E., The public's willingness to discuss their preference for organ donation with family members, Clinical Transplant 1999, 13, pp. 342.-348.

89 Zakon o presađivanju ljudskih organa u svrhu liječenja, op. cit. u bilj. 6, čl. 9., Zakon o primjeni ljudskih tkiva i stanica, op. cit. u bilj. 7, čl. 5.

90 Price, D., Legal and ethical aspects of organ transplantation, Cambridge University Press, 2000., str. 34.

91 Ibid.

92 Pravilnik o postupku obavještavanja o smrti osoba koje dolaze u obzir kao darivatelji dijelova ljudskog tijela zbog presađivanja u svrhu liječenja, Narodne novine, broj 152/2005. 
RH je prva u svijetu prema broju presađenih jetara i bubrega te druga u presađivanju srca, dok je lista čekanja smanjenja u posljednjih pet godina za $37 \% .^{94}$

Autor prije svega predlaže usklađivanje Kodeksa s aktualnim zakonodavstvom, no ako isto ne bi bilo ostvareno, tada je nužno da se same odredbe u Kodeksu oko uzimanja organa i tkiva od preminule osobe razrade preciznije i detaljnije.

Prilično je teško odrediti što je etično u određenim situacijama, pogotovo kodificirati etiku koja ipak nije i ne bi trebala biti određena samo Kodeksom, nego i pravnim normama prema uzoru na konstrukciju da pravo jest ili bi barem trebalo biti - negacija negacije morala. Kodeks u sebi uključuje deontološka, odnosno etička i pravna pravila, što bi značilo da bi se u obzir trebale uzeti i osnovne postavke i propisi aktualnog medicinskog prava. Prema cjelokupnoj razradi u radu postavlja se pitanje koliko je racionalno da se ide dalje od zakona i drugih propisa te se, iz već navedenih razloga, uistinu nameće potreba usklađivanja Kodeksa medicinske etike i deontologije s aktualnim zakonodavstvom. Isto emanira iz razrađenih etičkih i pravnih razloga, načela samoodređenja preminule osobe te sprječavanju samovolje i nesigurnosti u pravnoj i medicinskoj struci koja ponajprije treba osigurati zaštitu ljudskog života i integriteta. To i jest osnovna ideja opt out sustava koji dodatno pokušava proširiti broj potencijalnih darivatelja organa i tkiva. Ako je već potrebno staviti i pristanak obitelji kao jedan od uvjeta za uzimanje dijelova ljudskog tijela radi presađivanja, tada je riječ uistinu o ozbiljnom uvjetu (već spomenuta situacija tzv. dvostrukog veta) koji bi eventualno trebao biti reguliran zakonom.

No osim toga i ovakva regulacija u Kodeksu nije precizna, ostavlja veliki prostor diskreciji i raznovrsnom tumačenju te je od velike važnosti da Hrvatska liječnička komora, ako i ostavi pristanak obitelji kao uvjet, u skladu sa zahtjevima Europskog suda za ljudska prava u slučajevima Petrova v. Latvia i Elberte v. Latvia, barem detaljnije i sustavnije razradi određene mehanizme u Kodeksu oko pristanka obitelji o uzimanju dijelova ljudskog tijela radi liječenja. To se prije svega odnosi na definiranje same obitelji, odnosno onih srodnika koji imaju primat u odlučivanju oko istog pitanja, na rokove obavještavanja te na preciziranje pojma "etičnosti" uzimanja organa ili tkiva. Kodeks, prije svega, mora točno definirati obitelj, prema uzoru na ostale zakone gdje se na početku nude definicije ključnih pojmova ili jednostavno da se u okviru istog članka Kodeksa definiraju članovi obitelji te sustav suodlučivanja i prednosti glasova.

Ako je pristanak obitelji već jedan od uvjeta, nije na odmet uvesti i poseban institut informiranog pristanka kod odlučivanja obitelji kako se u Kodeksu ne bi pojavile one nejasnoće koje su analizirane u dvjema presudama Europskog suda za ljudska prava, a tiču se činjenice o neinformiranju obitelji o njihovu pravu na odlučivanje. Još jedno moguće rješenje jest da se uvede isključivo obavijest obitelji, umjesto samog pristanka, odnosno da se obitelj ne pita nužno za pristanak oko darivanja organa, nego da ih se obavijesti o činjenici da će organi biti uzeti ili da neće biti uzeti, sukladno odluci pacijenta. Kako je već spomenuto, razrađena europska praksa i nahođenje sugeriraju dijalog liječnika i obitelji, a da bi se to postiglo, mora se točno i sustavno definirati mehanizam provedbe zadužen za isto pitanje.

Veliku važnost kod ove problematike predstavlja i educiranje javnosti o ovom pitanju gdje bi se velik broj spomenutih i razrađenih situacija u radu mogao izbjeći tako da bi obitelji mogle u pravo vrijeme raspraviti sa svojim članovima koje su želje pojedinog člana u vezi s dariva-

94 Službene stranice Ministarstva zdravlja RH, URL=https://zdravlje.gov.hr/vijesti/hrvatska-je-najuspjesnija-clanica-eurotransplanta/369. Pristupljeno 5. siječnja 2017. 
njem organa i tkiva nakon smrti te bi i sam sustav postao još funkcionalniji, a svijest o darivanju organa zasigurno bi se podignula na još višu razinu.

\section{LITERATURA}

1. Bezinović, I., Determinizam i slobodna volja, Čemu, Vol. 5., No. 1, 2003., str. 43.-54.

2. Borovečki, A. (ur.), Mustajbegović, J. (ur.), Priručnik medicinske etike, Croatian Medical Journal: Medicinska naklada, Zagreb, 2010.

3. Bušić, M., Darivanje i presađivanje organa - "Hrvatski model”, Medix, god. XVII., br. 92/93, 2011., str. 144.-148.

4. Dove, S., E., et. al, Elberte v. Latvia: Whose tissue is it anyway - Relational autonomy or the autonomy ofrelations?, Medical Law International, p. 1-20, December 2015.

5. Fatović-Ferenčić, S. (ur.), Tucak A., (ur.), Medicinska etika, Medicinska naklada, Zagreb, 2011.

6. Filipović, V., Filozofijski rječnik, Nakladni zavod Matice hrvatske, Zagreb, 1984.

7. Guadagnoli, E., The public's willingness to discuss their preference for organ donation with family members, Clinical Transplant 1999, 13, 342.-348.

8. Lauc, Z., Moralitet - legitimitet - legalitet, Zbornik radova sa Šestog znanstveno-stručnoga interdisciplinarnoga skupa Ustavnopravne i obiteljsko-pravne aktualnosti, Osijek, 1. i 2. listopada 2015., Grafika, Osijek, 2016.

9. Kennedy, I., et. al, The case for "presumed consent" in organ donation, The Lancet, Vol. 351, No. 9116, pp. 1650-1652, 30 May 1998.

10. Matesanz, R., Cadaveric organ donation: comparison of legislation in various countries of Europe, Nephrology Dialysis Transplantation, Vol. 13, 1998, pp. 1632-1635.

11. Mašić, I., Medicinska deontologija - principi i praksa u Bosni i Hercegovini, Materia socio media, Vol. 20, No.1, 2008., str. 7.-13.

12. Michielsen, P., Presumed consent to organ donation: 10 years' experience in Belgium, Journal of The Royal Society of Medicine, Vol. 98, 1996, pp. 663-666.

13. Nedić, T., Kaznenopravni i medicinskopravni aspekti (ne)dozvoljenog uzimanja i presađivanja dijelova ljudskog tijela u Republici Hrvatskoj, Pravni vjesnik, 32, 1, str. 55.-77.

14. Nikšić, S., Načelo autonomije pacijenta u hrvatskom pravu, Bioetika i medicinsko pravo: Zbornik radova 9. bioetičkog okruglog stola, Rijeka, 2008., str. 163.-171.

15. Price, D., Human Tissue in Transplantation and Research: A Model Legal and Ethical Donation Framework, Cambridge University Press, Cambridge, 2009.

16. Price, D., Legal and ethical aspects of organ transplantation, Cambridge University Press, 2000.

17. Price, D., Legal framework governing deceased organ donation in the UK, British Journal of Anaesthesia, 2012, 108 (S1): pp. 68-72.

18. Roksandić Vidlička, S., Aktualna pitanja pojedinih kaznenih djela protiv zdravlja ljudi u svjetlu donošenja nacrta izmjena hrvatskog Kaznenog zakona, Godišnjak Akademije pravnih znanosti Hrvatske, Vol. 1, No. 1, 2010., str. 93.-146.

19. Roksandić Vidlička, S., Galiot, V., Eksperimenti na ljudima kao zločin protiv čovječnosti: Od Nürnberškog Medicinskog suđenja do predmeta Pfizer, Godišnjak Akademije Pravnih znanosti Hrvatske, VII (2016), 1/2016, str. 186.-253. 
20. Salihbegović, E., Medicinska praksa i etičko pitanje, Ministarstvo zdravstva kantona Sarajevo, Sarajevo, 2008.

21. Samanta, J., Samanta, A., Medical Law, Palgrave Macmillian, East Kilbride, 2011.

22. Talanga, J., Odnos liječnika i pacijenta prema medicinskoj etici, Bogoslovska smotra, Vol. 76, br. 1, 2006., str. 47.-59.

23. Turković, K., Pravo na odbijanje medicinskog tretmana u Republici Hrvatskoj, Medicina, Vol. 44, No. 2, 2008., 158.-170.

24. Turković, K., Roksandić Vidlička, S. (ur.), Informirani pristanak, Sveučilište u Zagrebu, Zagreb, 2009.

25. Turković, K., Roksandić Vidlička, S., Reforma kaznenog zakonodavstva u području zdravstva, Zbornik radova: Aktualnosti kaznenog zakonodavstva u području zdravstva, Novalja, 2011., str. 111.-137.

26. Veatch, R., M., Medical Ethics, Second edition, Kennedy Institute of Ethics, Georgetown University, Jones and Barlett Publishers, Sudbury, 1997.

27. Vidaković-Mukić, M., Opći pravni rječnik, Narodne novine, Zagreb, 2006.

28. Visković, N., Teorija države i prava, Birotehnika, Zagreb, 2001.

29. Wilkinson, T., M., Individual and family consent to organ and tissue donation: is the current position coherent?, Journal of Medical Ethics, October 2005, Volume 31, Issue 10, pp. 587-590.

30. Žepić, M., Latinsko-hrvatski rječnik, Školska knjiga, Zagreb, 2000., str. 44.

31. Živčić-Ćosić, S. et al., Development of the Croatian model of organ donation and transplatation, Croatian Medical Journal, Vol. 54, No. 1, 2013, pp. 65-70.

\section{PRAVNI AKTI}

1. Elberte v. Latvia, No. 61243/08, ECHR Judgment 13/4/2015 (Section IV).

2. Kazneni zakon, Narodne novine, broj 125/2011, 144/2012, 56/2015, 61/2015.

3. Kodeks medicinske etike i deontologije, Narodne novine, broj 55/2008, 139/2015.

4. Konvencija o ljudskim pravima i biomedicini, Narodne novine, Međunarodni ugovori, broj 13/2003.

5. Konvencija o zaštiti ljudskih prava i temeljnih sloboda, MU 18/1997, 6/1999, 14/2002, 13/2003, 9/2005, 1/2006, 2/2010.

6. Obiteljski zakon, Narodne novine, broj 103/2015.

7. Organtransplantationsgesetz - OTPG, BGBl. I Nr. 108/2012.

8. Petrova v. Latvia, No. 4605/05, ECHR Judgment 24/9/2014 (Section IV).

9. Pravilnik o podacima i načinu vođenja dokumentacije o mogućim darivateljima dijelova ljudskog tijela radi presađivanja s umrle osobe, Narodne novine, broj 188/2003, 152/2005, 152/2005, 144/2012.

10. Pravilnik o postupku obavještavanja o smrti osoba koje dolaze u obzir kao darivatelji dijelova ljudskog tijela zbog presađivanja u svrhu liječenja, Narodne novine, broj 152/2005.

11. Predmet C-29/14, Presuda Suda (treće vijeće) od 11. lipnja 2015., Europska komisija protiv Republike Poljske.

12. Pretty v. United Kingdom, Application No. 2346/02.

13. The Declaration of Istanbul on Organ Trafficking and Transplant Tourism, The Transplantation Society (TTS) and International Society of Nephrology (ISN) in Istanbul from April 30 to May 
2, 2008, tekst dostupan na: http://www.declarationofistanbul.org/about-the-declaration/structure-and-content\#prea mble.

14. Ustav Republike Hrvatske, Narodne novine, broj 56/1990, 135/1997, 8/1998, 113/2000, 124/2000, 28/2001, 41/2001, 55/2001, 76/2010, 85/2010, 5/2014.

15. Y. F. v. Turkey, Application no. 24209/94, para 43.

16. Zakon o liječništvu, Narodne novine, broj 121/2003, 117/2008.

17. Zakon o krvi i krvnim pripravcima, Narodne novine, broj 79/2006, 124/2011.

18. Zakon o medicinski pomognutoj oplodnji, Narodne novine, broj 86/2012.

19. Zakon o obveznim odnosima, Narodne novine, br. 35/2005, 41/2008, 125/2011, 78/2015.

20. Zakon o presađivanju ljudskih organa u svrhu liječenja, Narodne novine, broj 144/2012.

21. Zakon o primjeni ljudskih tkiva i stanica, Narodne novine, broj 144/2012.

22. Zakon o transplantaciji organa, Službeni glasnik Republike Srbije, broj 72/2009.

23. Zakon o uzimanju i presađivanju dijelova ljudskog tijela u svrhu liječenja, Narodne novine, broj 177/2004, 45/2009.

24. Zakon o zaštiti prava pacijenata, Narodne novine, broj 169/2004, 37/2008.

25. Zakon o zdravstvenoj zaštiti, Narodne novine, broj 150/2008, 71/2010, 139/2010, 22/2011, 84/2011, 154/2011, 12/2012, 35/2012, 70/2012, 144/2012, 82/2013, 159/2013, 22/2014, $154 / 2014,70 / 2016$.

\section{MREŽNI IZVORI}

1. Službene stranice Hrvatske donorske mreže, URL=http://www.hdm.hr/2008/11/11/istanbulska -deklaracija. Pristupljeno 13. studenoga 2016.

2. Službene stranice Ministarstva zdravlja RH, URL=https://zdravlje.gov.hr/vijesti/hrvatska-je-najuspjesnija-clanica-eurotransplanta/369. Pristupljeno 5. siječnja 2017. 


\section{FAMILY CONSENT FOR ORGAN OR TISSUE REMOVAL FROM A DECEASED PERSON FOR TRANSPLANTATION PURPOSES IN THE REPUBLIC OF CROATIA}

\section{Summary}

The Republic of Croatia is a country with the system of presumed consent donation of organs and tissues after death, where the consent of the family, according to law, is not one of the conditions for organ or tissue removal for transplantation purposes. However, the consent is a condition required by the Codex of Medical Ethics and Deontology. The author primary proposes harmonization of the Codex with current legislation. Accordingly, this paper primarily analyses the typology of the Codex, ethical issues and ethical and positivist reasons to harmonize the Codex with current legislation. Furthermore, although the author in the first place considers that the Codex should be in line with legislation, he also considers the provision of family consent for organ and tissue removal itself flawed and poorly developed. In this regard, the author considers the comparative legislation and judgments of the European Court of Human Rights, analyses current provisions of the Codex in the part of the removal and transplantation of organs and tissues from deceased persons, states the facts that the Codex should contain so as to make the mechanism of family consent for organ and tissue removal and donation after death more effective. In fact, if the author's original proposal for harmonization of the Codex with the current legislation is not accepted, a more detailed and precise elaboration of the mentioned current provisions of the Codex will be suggested. This will include exact definition of the family and relatives, exact deadlines and ways of informing the family, but also refining the concept of "ethical" according to the Codex in part of the organ and tissue donation and removal from the deceased person.

Keywords: $\quad$ Family consent, Codex of Medical Ethics and Deontology, organs, tissues, ethics

Tomislav Nedić, LLM, PhD candidate at the Faculty of Law in Osijek. Orahovička 47, 31000 Osijek, Republic of Croatia. E-mail address: nedict@gmail.com. 